\title{
STRUCTURE AND MECHANICAL PROPERTIES OF AUSTENITIC STEELS AFFECTED BY SIGMA-PHASE PRECIPITATION DUE TO EXPOSURE TO HIGH TEMPERATURES
}

\author{
SPREMEMBA STRUKTURE IN MEHANSKIH LASTNOSTI \\ AUSTENITNIH JEKEL ZARADI IZLOČANJA SIGMA FAZE PRI \\ VISOKIH TEMPERATURAH
}

\author{
Ladislav Kander, Šárka Stejskalová, Petr Čížek \\ ${ }^{1}$ Material and Metallurgical Research Ltd., Pohranicni 693/31, Vítkovice, 70300 Ostrava, Czech Republic \\ ladislav.kander@mmvyzkum.cz \\ Prejem rokopisa - received: 2016-07-29; sprejem za objavo - accepted for publication: 2018-03-22
}

doi:10.17222/mit.2016.230

\begin{abstract}
The paper deals with the change in the structure and mechanical properties of the austenitic-steel grades TP347 HFG, Super $304 \mathrm{H}$ and HR3C, representing the most frequently used materials for superheaters and preheaters in the ultra-supercritical power industry. The effect of plastic deformation applied during the bending of tubes with different bend radii on the mechanical properties and structure was studied on material samples with or without post-bend heat treatment (PBHT). The mechanical properties of tubes with a small wall thickness were studied using the small-punch test (SPT) and miniaturized tensile-test specimens. From the results obtained, it can be concluded that the mechanical properties and the structure were significantly influenced after a one-year exposure to the working temperature. Various amounts of the $\sigma$-phase were found in the extrados parts of the bends even in the cases when the bends were only exposed to high temperatures without any loading. The effects of the $\mathrm{PBHT}$ and the bend radius on the mechanical properties and the structure were also evident. A drop in the fracture energy due to the presence of the $\sigma$-phase in the structure was clearly detected from the force-displacement record of the SPT.

Keywords: austenitic stainless steels, tube bends, $\sigma$-phase precipitation, small-punch test

Avtorji v članku obravnavajo strukturne in mehanske spremembe austenitnih jekel vrste TP347 HFG, Super 304H in HR3C, ki se najpogosteje uporabljajo za močno obremenjene dele visokotemperaturnih izmenjevalnikov toplote $\mathrm{v}$ zahtevni industriji proizvodnje električne energije. Raziskovali so vpliv plastične deformacije zaradi hladnega krivljenja cevi različnih premerov na mehanske lastnosti pred krivljenjem in/ali po toplotni obdelavi (PBHT; angl.: post-bend heat treatment). Mehanske lastnosti cevi z manjšo debelino stene so ugotavljali s pomočjo preizkusov lezenja z vtiskovanjem trna (SPT; angl.: small-punch test) in nateznim preizkusom na miniaturnih preizkušancih. Na osnovi dobljenih rezultatov ugotavljajo, da so se mehanske lastnosti in struktura jekel močno spremenile že po enoletni izpostavitvi materialov na delovno temperaturo. V preizkušancih so našli različne vsebnosti $\sigma$-faze celo v primerih, ko so bili ukrivljeni (deformirani) deli cevi neobremenjeni, a izpostavljeni visokim temperaturam. Očiten je bil prav tako vpliv PBHT in premera kolen (ukrivljenosti cevi) na mehanske lastnosti in strukturo preiskovanih jekel. Preko zapisa sila-pomik med SPT preizkusom so jasno zaznali zmanjšanje energije loma zaradi prisotnosti $\sigma$-faze v strukturi jekla.

Ključne besede: austenitna nerjavna jekla, hladno ukrivljene cevi, izločanje $\sigma$-faze, tlačni preizkus lezenja z majhnim trnom
\end{abstract}

\section{INTRODUCTION}

The nowadays worldwide trend of a transition from the power plants working under supercritical steam conditions to modern ones working at ultra-supercritical (USC) parameters brings about new materials used for the components working in these demanding conditions. The mostly used materials are nickel alloys and austenitic steels with high $\mathrm{Cr}$ contents. A long-term exposure of these steels to high temperatures leads to the precipitation of the $\sigma$-phase, an intermetallic $\mathrm{Fe}$ - $\mathrm{Cr}$ phase that forms in austenitic steels during long-term exposures to high temperatures. This phase precipitates at above $400-500{ }^{\circ} \mathrm{C}$ and is stable up to $700{ }^{\circ} \mathrm{C}$. In Cr-Ni austenitic steels, the $\sigma$-phase formation is stimulated by increasing the $\mathrm{Cr}$ content above $17-20 \%$ of mass fractions and is prevented by increasing the $\mathrm{Ni}$ content and also by increasing the carbon concentration. The presence of the $\sigma$-phase generally leads to embrittlement of the material at ambient as well as increased temperatures. Since the $\sigma$-phase is enriched with $\mathrm{Cr}$, the diffusion of $\mathrm{Cr}$ is usually regarded as one of the controlling factors for its precipitation. Besides the chromium content, many other factors affect the formation of the $\sigma$-phase. Diffusion of another substitutional element like Mo may also be important. In general, all ferrite-forming elements like $\mathrm{Cr}, \mathrm{Nb}$, Ti, Mo or $\mathrm{W}$ promote the $\sigma$-phase appearance. Due to differences in the diffusion rate of alloying elements in face-centred cubic (FCC) and body-centred cubic (BCC) lattices, the formation of the $\sigma$-phase in austenite is about 100 times slower than in ferrite. ${ }^{1}$ An extensive study of advanced steels for USC boilers confirmed the effect of cold bending on the $\sigma$-phase precipitation. ${ }^{1}$ The main goal of this study was to quantify and qualify the $\sigma$-phase precipitation in time and to assess the degradation of the 
material properties of the tubes due to the presence of the $\sigma$-phase.

\section{EXPERIMENTAL PART}

Three grades of austenitic steels (Super 304H, HR3C and TP347 HFG) were used for the experimental program. Cold-bend tubes with $\phi 38 \mathrm{~mm} \times 6.3 \mathrm{~mm}$ in the as-bent state (cold worked without any further heat treatment) and after PBHT (heat treated after bending) were used as the experimental materials. At first, the mechanical properties and microstructures were analysed, and then rings about $15 \mathrm{~mm}$ long were cut out from the bent parts of the tubes, with bend radii of R60, R80 and R100 and placed into a boiler where they were exposed, for one year, either to a temperature range of $635-695{ }^{\circ} \mathrm{C}$ or a range of $726-775{ }^{\circ} \mathrm{C}$, without any loading. The analyses performed after a year's exposure confirmed that the $\sigma$-phase appeared in almost all the sample. The effect of the $\sigma$-phase on the mechanical properties and fracture behaviour was then examined using miniaturized tensile tests and SPT. ${ }^{2}$ The effect of the plastic deformation applied during the bending of the tubes on the structure and the mechanical properties was also studied. The positive effect of solution annealing on the structure was quantified, too.

\section{INVESTIGATION METHOD}

As the standard tensile test is not sensitive enough to quantify the effect of the $\sigma$-phase, we used a special SPT method originally developed for a residual-lifetime assessment of power-plant components. This testing method is covered in this case by a draft of the ISO standard. The SPT technique is an almost non-destructive technique for characterizing the mechanical properties, especially of service-exposed plant components. The basic principle of the SPT method is to penetrate a small volume of the experimental material (Figure 1). The SPT technique utilises a small disc specimen, $8 \mathrm{~mm}$ in diameter and $0.5 \mathrm{~mm}$ in thickness, clamped around its circumference and indented by a spherical punch until its failure. ${ }^{3}$ The relationship between the monotonic load and displacement records is used to correlate tensile- and fracture-toughness parameters (Figure 1) as well as the fracture energy evaluated as the area under the deflection curve.

\section{RESULTS}

The microstructures of all the specimens were investigated with light optical microscopy (LOM). Specimens were electrolytically etched in $10-\%$ oxalic acid and the microstructure evaluation showed that all the samples of the tube bends exposed to the elevated temperature contained various amounts of the $\sigma$-phase in dependence on the temperature, bend radii and PBHT. In accordance

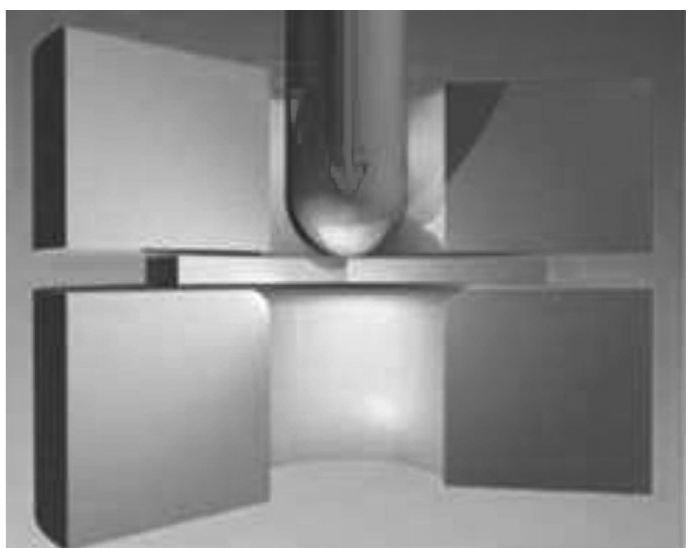

Figure 1: Principle of the small-punch test and a typical SPT record

with the theoretical presumption of the effect of stress on the kinetics of the $\sigma$-phase precipitation, the specimens of all the examined grades with small bend radii and tested in the as-bent state contained the most of the $\sigma$-phase. ${ }^{4}$ At the same time, in the specimen having a bend radius of $\mathrm{R} 100$ (corresponding to the minimum amount of cold-work deformation) the minimum amount of the $\sigma$-phase precipitated. ${ }^{5}$ The specimens of all the tested steels exposed to the higher temperature range contained dramatically more $\sigma$-phase, distributed throughout the whole wall thickness; however, the rings exposed to lower temperatures contained not only a smaller portion of the $\sigma$-phase, but their particles were found mostly near the outer surface of the extrados.

Figures $\mathbf{2}$ to $\mathbf{4}$ compare the amounts and distributions of the $\sigma$-phase in the specimens with various bend radii made of all three steel grades and tested in both temperature ranges. These figures show that the $\sigma$-phase particles are relatively fine and equally distributed in all the specimens, but the extent of the precipitation is the lowest in the case of steel TP347 HFG. On the contrary, steel HR3C (Figure 4) was affected more dramatically; the particles of the $\sigma$-phase were coarse and heavily distributed in the matrix, again with a difference in the amount and distribution between the as-bent rings and the rings that underwent PBHT. On the other hand, the precipitation of the $\sigma$-phase in steel HR3C exhibited different features: its particles in the specimens after PBHT, tested at lower temperatures formed clouds of small precipitates beneath the outer surface of the tube; but in the specimens without PBHT, they formed more or less continuous rows along the grain boundaries. The exposure to higher temperatures caused the coarsening of the $\sigma$-phase in the tube bends that would negatively affect the toughness of the materials.

Figure 4 then shows the structures of the rings made of the Super $304 \mathrm{H}$ steel. In this case, the most pronounced differences in the distribution and size of the $\sigma$-phase particles in the samples with and without PBHT, among all the tested steel grades, were detected.

The presence of an even very small volume of the $\sigma$-phase in the structure results in a drop of the fracture 
energy, which can be clearly observed in the force-displacement record of the SPT. ${ }^{6}$ The SPTs were performed on the specimens made of all three steels and Figures 5 to 7 show the effect of PBHT on the fracture energy of the specimens tested after a year's exposure to high temperature for the tube bends with the minimum bend ra- dius (left) and the effect of a long-term high-temperature exposure on the decrease in the fracture energy in the tube bends with the minimum bend radius (right) for TP347 HFG, HR3C and Super 304H steels. The maximum drop in the fracture energy after the high-temperature exposure is evident in the tube bend made of the

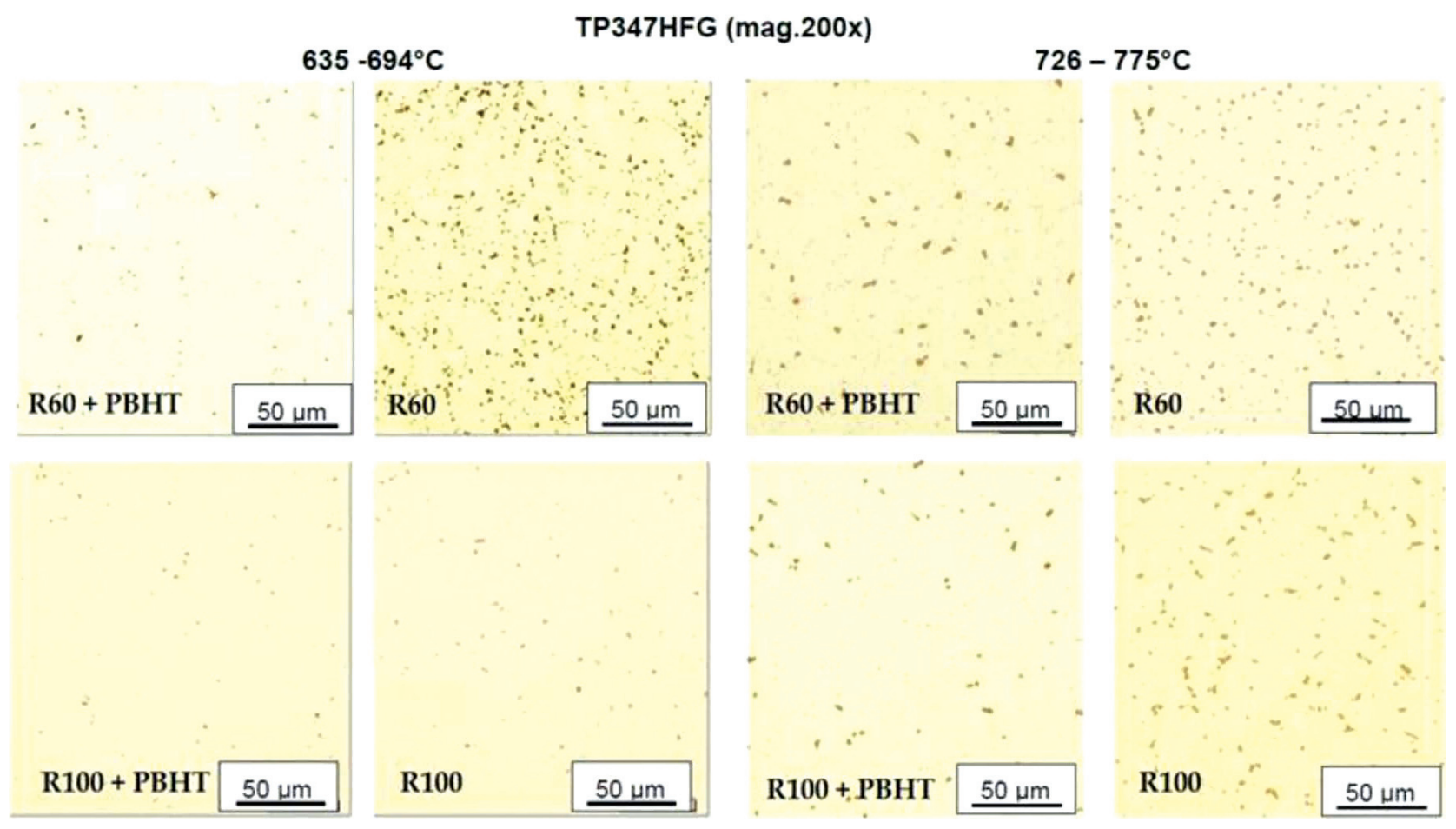

Figure 2: $\sigma$-phase distribution in various samples made of TP347HFG steel after exposure to lower and higher temperatures

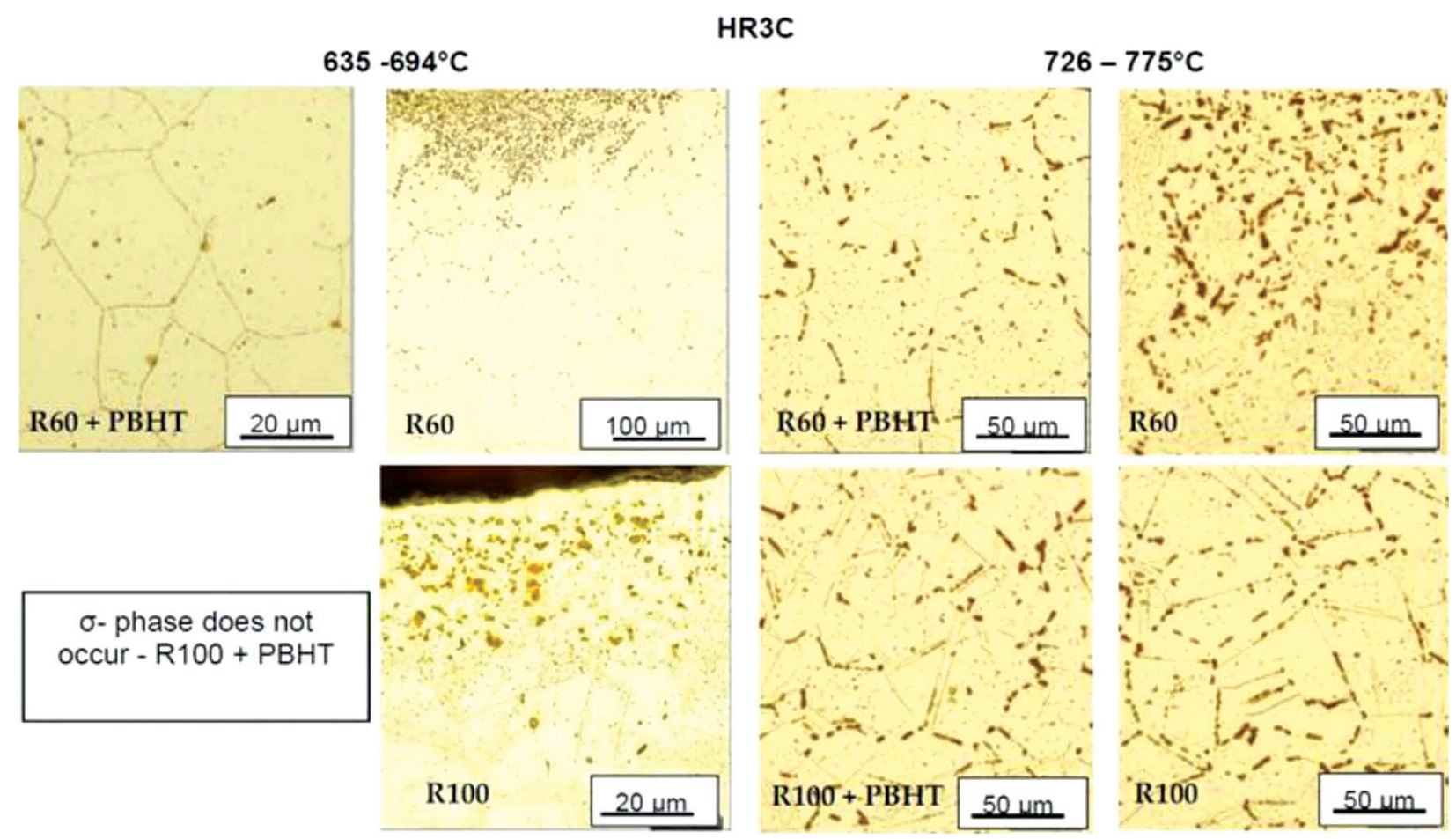

Figure 3: $\sigma$-phase distribution in various samples made of HR3C steel after exposure to lower and higher temperatures 
L. KANDER et al.: STRUCTURE AND MECHANICAL PROPERTIES OF AUSTENITIC STEELS AFFECTED BY ...

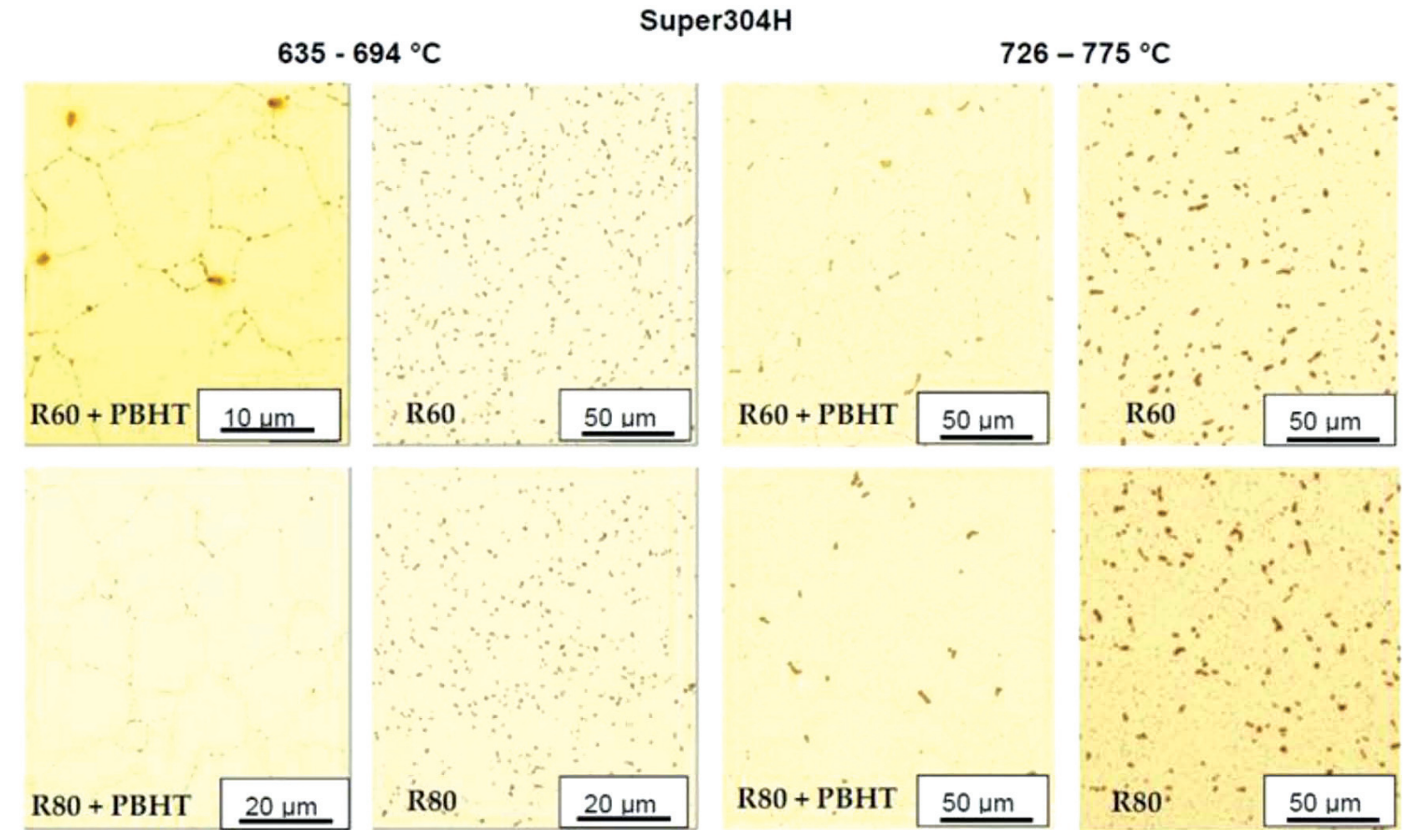

Figure 4: $\sigma$-phase distribution in various samples made of Super 304H steel after exposure to lower and higher temperatures
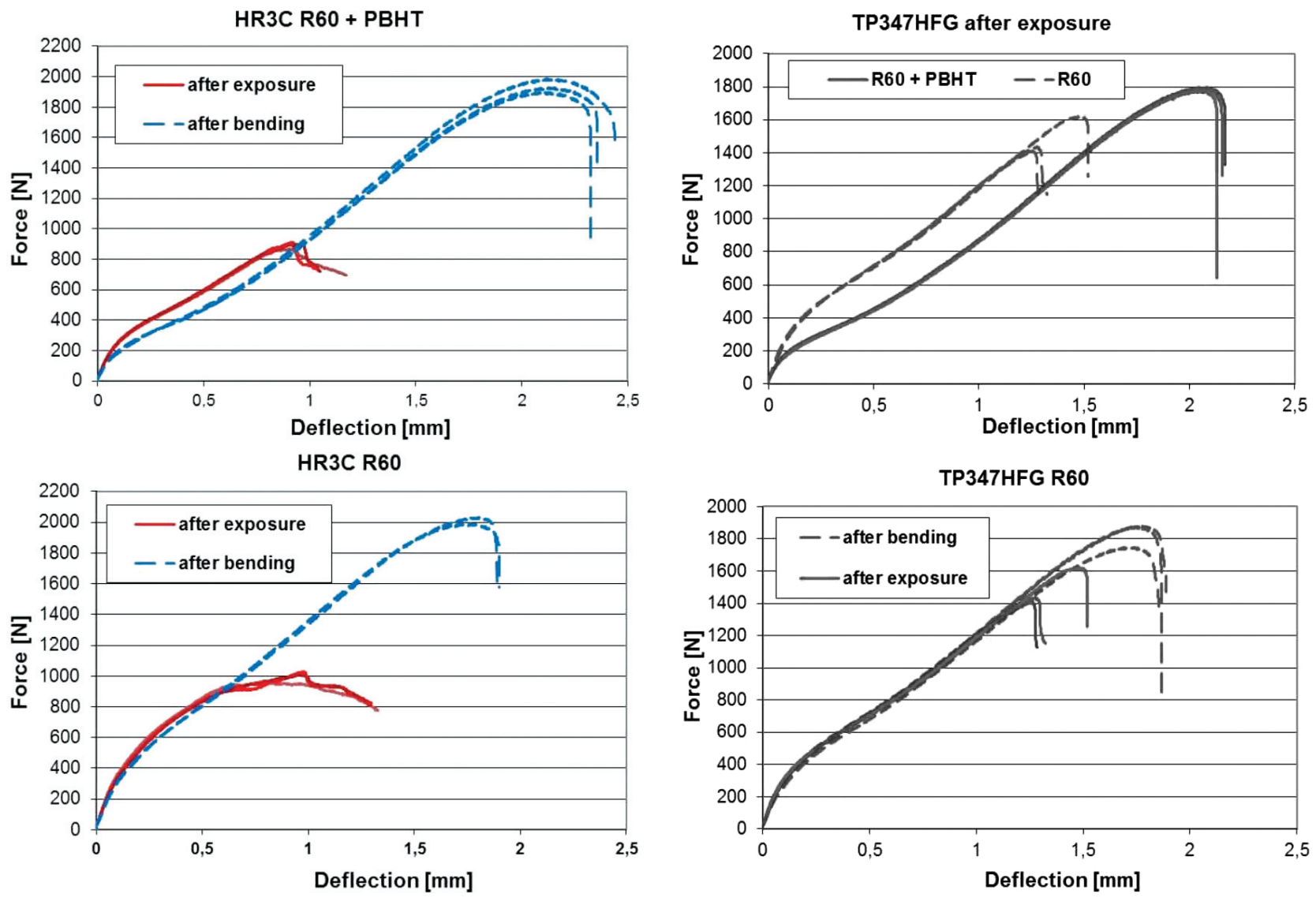

Figure 5: Force versus displacement for tube bend TP347HFG in the as-bent state and after the exposure

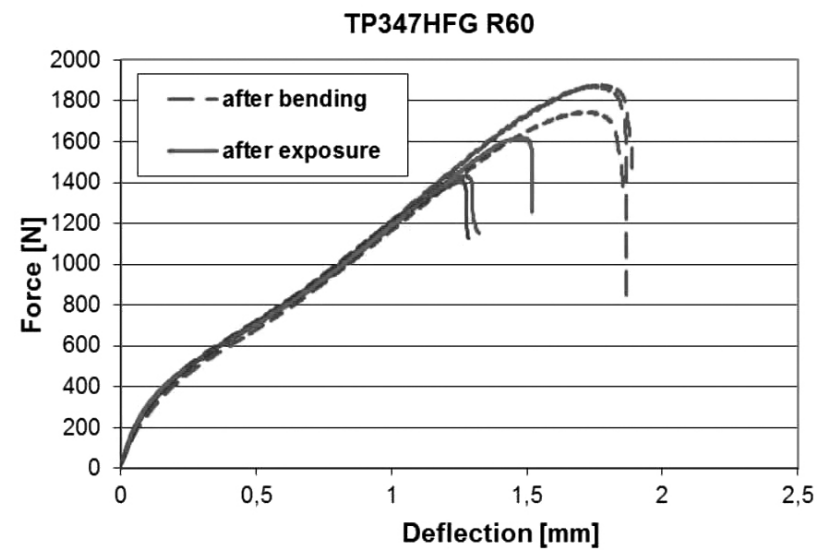

Figure 6: Force versus displacement for tube bend HR3C in the as-bent state and after the exposure 

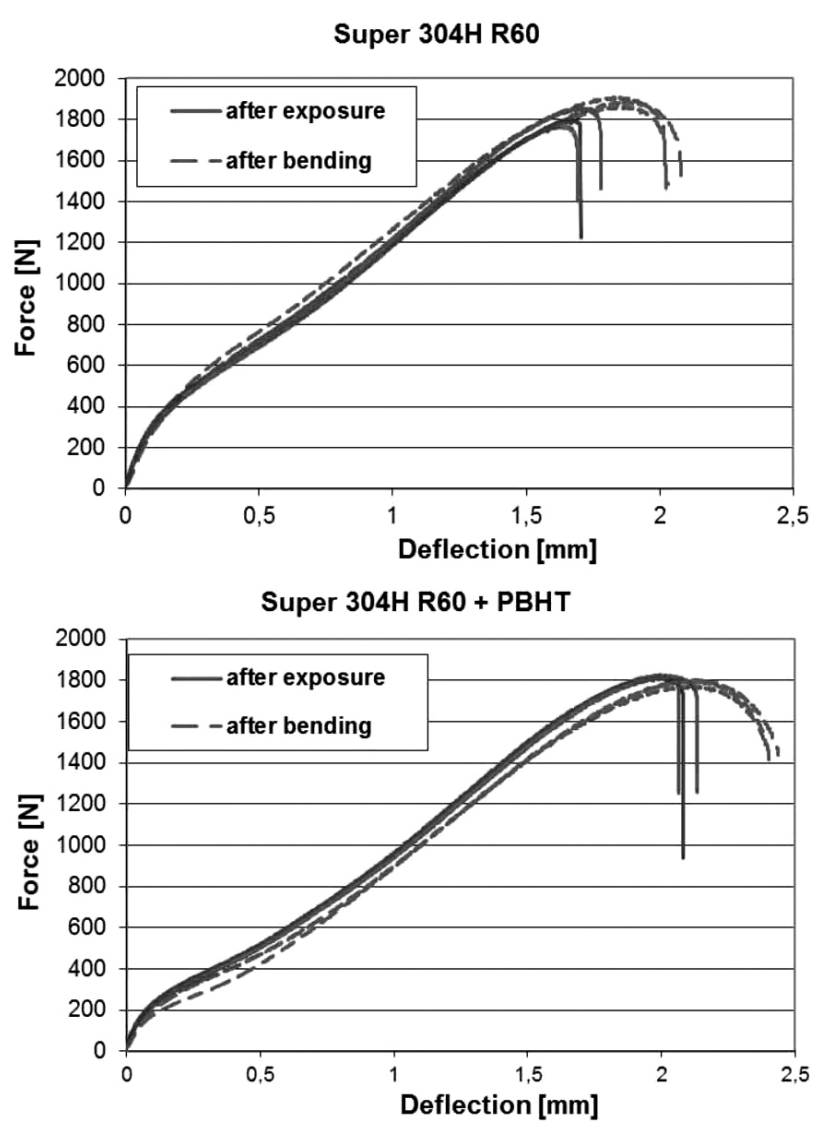

Figure 7: Force versus displacement for tube bend Super $304 \mathrm{H}$ in the as-bent state and after the exposure

HR3C steel (Figure 6) and the change is so great that probably another mechanism also played a role in this process. When comparing the obtained curves with the results of the microstructural analysis, it seems that the curve showing the drop in the force versus the displacement for the specimen prepared from the HR3C steel could be the result of the $\sigma$-phase precipitation along the grain boundaries of the steel. The smallest change in the fracture energy becomes evident in the tube bends made of the Super 304H steel (Figure 7).

SPT specimens were also successfully used for an evaluation of an energy-drop impact due to the $\sigma$-phase brittleness, also in the work where the effects of a long-time operation on the structure and properties of Tp347 HFG were studied. ${ }^{5}$

\section{DISCUSSION}

The presented results indicate that the $\sigma$-phase is a microstructural factor that plays an important role during an exposure of a pressurised part in USC power plants. Detecting the $\sigma$-phase in the structures of tube bends after a year's exposure to high temperatures, without any loading is very important. It is necessary to point out that the examined samples were tube bends and the $\sigma$-phase was detected just at the extrados, on the outer surface (at lower exposure temperatures) or across the whole wall thickness of the extrados (at higher exposure temperatures). The amount of the $\sigma$-phase in the tube bends reflects the amount of deformation energy put into the material during cold bending, which decreases the activation energy of the $\sigma$-phase precipitation. So, the samples with PBHT and with higher bend radii (and therefore lower energy input) show a low, if any, amount of the $\sigma$-phase. This fact is supported by the results of the microstructural analysis made on the straight parts of identical tube bends after the same high-temperature exposure (Figure 8).

This means that the tube bends with low bend radii (R60, R80 - corresponding to deformation of 1,6 and $2,1)$ require PBHT to minimalize the presence of the $\sigma$-phase in the structure. When the exposure temperature is higher than $700{ }^{\circ} \mathrm{C}$, it is necessary to perform PBHT even for the bend radii of R100 (corresponding to deformation of 2,6) in order to minimize, or at least postpone, the precipitation of the $\sigma$-phase.

\section{CONCLUSIONS}

After an exposure to a temperature range of 635-694 ${ }^{\circ} \mathrm{C}$, small amounts of $\sigma$-phase were found near the surfaces of all the specimens; at higher temperatures of the exposure, the $\sigma$-phase was found across the whole wall thickness of the extrados. The effects of the bend radii were clearly identified - small bend radii contain more $\sigma$-phase compared to the bigger ones. In order to minimalize the volume of the $\sigma$-phase in the structure of an extrados with a small bend radius, it is necessary to
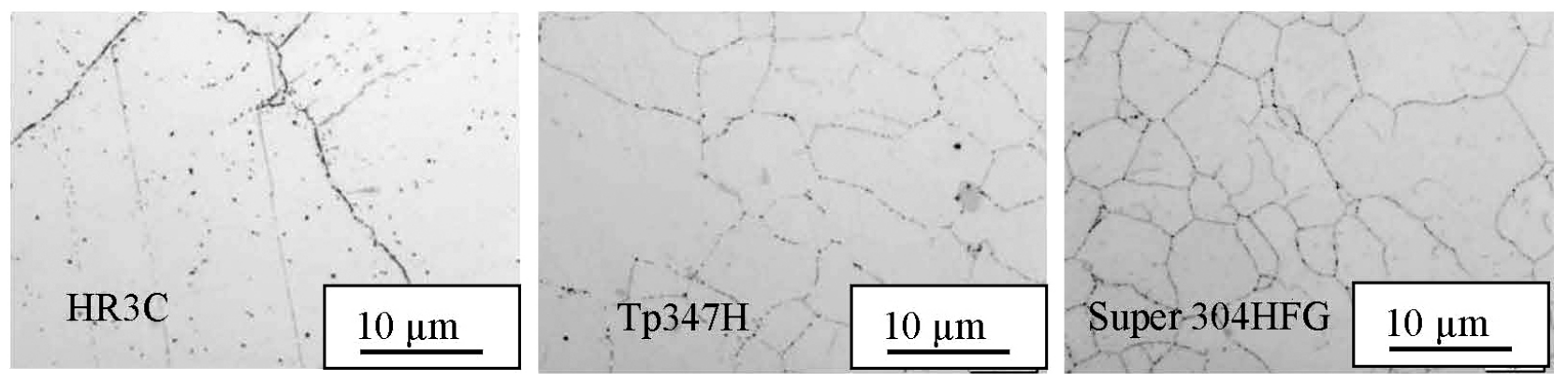

Figure 8: No signs of $\sigma$-phase precipitation in the straight parts of tube bends after a high-temperature exposure 
carry out post-bend heat treatment. Small-punch testing can be used as it is advantageous for the evaluation of the effect of the $\sigma$-phase on the mechanical and toughness properties of austenitic heat-resistant steels because a large amount of the $\sigma$-phase significantly affects the fracture energy of SPT.

\section{Acknowledgment}

This paper was created within project no. LO1203 "Regional Materials Science and Technology Centre Feasibility Program" funded by the Ministry of Education, Youth and Sports of the Czech Republic.

\section{REFERENCES}

${ }^{1}$ Z. Kuboň, Š. Stejskalová, L. Kander, Effect of sigma phase on fracture behaviour of steels and weld joints of components in power industry working at supercritical conditions, Austenitic Stainless Steels - New Aspects, Intech, Croatia 2017, 208

${ }^{2}$ Small Punch Test Method for Metallic Materials, CEN workshop agreement CWA 15627, December 2007

${ }^{3}$ J. Horváth, P. Král, J. Janovec, V. Sklenička, The effect of sigma-phase formation on long-term durability of Super $304 \mathrm{H}$ steel, Proc. of Metal 2015, $24^{\text {rd }}$ International Conference on Metallurgy and Materials, Ostrava, Tanger, 2015, 505-510

${ }^{4} \mathrm{~J}$. Barcik, Mechanism of sigma-phase precipitation in $\mathrm{Cr}-\mathrm{Ni}$ austenitic steels, Materials Science and Technology, 4 (1988), 5-15

5 Š. Stejskalová, L. Kander, Š. Hermanová, The change of the structure and mechanical properties of the austenitic steels after exposure at the critical temperature, Materials Science Forum, 891 (2017), 330-334

${ }^{6}$ L. Kander, L. Korčáková, The influence of sigma phase precipitation on mechanical properties of $\mathrm{Tp} 347 \mathrm{H}$ austenitic steels after 100,000 hour service in coal-fired power plant, Proc. of Metal 2015, $24^{\text {rd }}$ International Conference on Metallurgy and Materials, Ostrava, Tanger, 2015, 693-698 